\title{
Use of artificial mineral licks by white-tailed deer in Louisiana
}

\author{
STEPHEN R. SCHULTZ AND MARK K. JOHNSON
}

\author{
Authors are assistant professor and professor, School of Forestry, Wildlife, and Fisheries, LAES, Louisiana State \\ University Agricultural Center, Baton Rouge 70803.
}

\begin{abstract}
We examined white-tailed deer (Odocoileus virginianus) use of artificial mineral licks on 3 properties in southcentral Louisiana. High deer use of licks extended longer into summer and fall than reported for areas in more northern latitudes. Estimated monthly mineral consumption averaged $538.0 \mathrm{~g} /$ deer $(\mathrm{SE}=70.8)$ and was associated with total moisture and crude protein reported for native plants on forest range in central Louisiana. Consumption from individual licks was positively associated with adjacent soil $P$ concentration $(P<0.001)$.
\end{abstract}

Key Words: licks, mineral licks, Odocoileus virginianus, supplementation

Mineral licks have long been recognized as areas to which wild animals, particularly ungulates, are attracted. All native North American ruminants use licks (Jones and Hanson 1985). The major element sought from licks is sodium (Na) (Stockstad et al. 1953, Jones and Hanson 1985). Physiological mineral imbalances and increased lick use are likely to occur on most ranges during spring and early summer when vegetation contains relatively high percentages of water and potassium (K) (Dasmann 1971, Weeks and Kirkpatrick 1976, Weeks 1978, Jones and Hanson 1985).

Many mineral mixtures have recently been introduced and marketed for supplementing deer. The purpose of this study was to evaluate white-tailed deer (Odocoileus virginianus) use of one of these products in southcentral Louisiana, to examine annual consumption trends, and to investigate mineral consumption versus soil geochemistry and versus the annual vegetative cycle.

\section{Materials and Methods}

Three properties in East Feliciana Parish, Louisiana, were used for this study: Avondale Hunting Camp (Avondale), Shades Plantation (Shades), and Blairstown Plantation (Blairstown). Treatment areas on these properties were $351 \mathrm{ha}, 337 \mathrm{ha}$, and $980 \mathrm{ha}$, respectively, of upland loblolly pine (Pinus taeda) with mixed hardwood habitat and pasture (Schultz 1990). Study area soils were poorly to moderately well-drained soils of low fertility of the Providence-Oliver and Providence-Lexington associations (U.S. Soil Conserv. Serv. 1971).

Forty-two licks were established during March through June 1988: 12 on Avondale, 14 on Shades, and 16 on Blairstown. Rack $^{\text {TM }}$ deer mineral [V.M.S., Inc., Montgomery, Ala.: calcium (Ca)-min. 16\%, max. 19\%; phosphorus $(P)-$ min. 10\%; salt $(\mathrm{NaCl})-\min .31 \%$, max. 35\%; magnesium $(\mathrm{Mg})-\min .0 .75 \%$;

\footnotetext{
Approved for publication by the Director, Louisiana Agricultural Experiment Station as Manuscript 91-22-5461.

The authors thank Messrs. G. Berger, T. Jones, B. Jones, and F. Jones for use of their properties.

This study was funded by the Louisiana Agricultural Experiment Station under McIntire-Stennis project LAB02154. Additional support was provided by Safari Club International and Mr. J.S. Mcllhenney. Deer mineral was donated by V.M.S., Inc., Montgomery., Ala.

Manuscript accepted 14 Apr. 1992.
}

cobalt $(\mathrm{Co})-\min .0 .0001 \%$; copper $(\mathrm{Cu})-\min .0 .01 \%$; iodine (I) -min. 0.005\%; iron (Fe)-min. 0.70\%; manganese (Mn) 0.10\%; selenium $(\mathrm{Se})-\min .0 .0026 \%$; zinc $(\mathrm{Zn})-\min .0 .10 \%$; Vitamin $A-\min .265,000$ I.U. per kg; Vitamin D-3-min. 110,000 I.U. per $\mathrm{kg}$ ] was used for this study because it provided broad-spectrum mineral supplementation representative of the products available and because it included the minerals recommended for supplementing the diets of cattle in Louisiana (Chapman 1984, 1985).

Licks were distributed as evenly as possible on each property considering other land-use practices and topography (so licks would not flood or be exposed to significant runoff). Licks in areas open to cattle grazing on Blairstown were fenced to exclude cattle. Each lick was established using one 11.3-kg mineral block in an excavated depression surrounded by $11.3-\mathrm{kg}$ granulated mineral such that the lick was to ground level. Licks were monitored monthly through December 1989 and recharged with granulated mineral back to ground level if used. The amount of mineral added to each lick was measured monthly.

In order to assess which species of animals were utilizing licks, the area immediately surrounding each lick was monitored for tracks during each recharging procedure. Our objective was not to quantify lick utilization via track counts but rather to identify which species had visited licks.

Estimates of relative numbers of deer potentially using licks on the areas were required for mineral consumption values to have practical utility. In order to estimate the relative numbers of deer that potentially used licks, we conducted 3 Hayne's strip censuses (Hayne 1949) annually during September on each area (Schultz 1990). We assumed that fawns of the year did not impact mineral consumption until September censuses and that decreases in herd populations occurred each winter and were primarily hunting related. Comparisons among properties were made on the assumption that mortality other than from legal harvests was similar among areas.

Monthly mineral consumption was compared with monthly composition of native plants on forest range in central Louisiana (Campbell et al. 1954). A soil sample was collected to a depth of 15 $\mathrm{cm}$ within $9 \mathrm{~m}$ of each lick and analyzed by the Soil Testing Laboratory, Department of Agronomy, Louisiana Agricultural Experiment Station, Louisiana State University Agricultural Center. Soil test results (Table 1) were compared to average monthly mineral consumption from individual licks to examine relationships between soil geochemistry and lick use.

The effects of study area and month of the year on mineral consumption per deer were examined using analysis of variance (Ray 1982). We used a block design instead of a split-plot design for analyses because we desired to examine the effects of month of the year and not the repeated measure of month of the study. Mineral consumption was compared among areas, seasons, and months of the year using orthogonal contrasts (Steel and Torrie 1980:364-365). Pearson's correlation coefficient ( $r$ ) was used to 
Table 1. Average soil mineral concentrations (ppm), pH, conductivity (Cond.; UMHOS), and salts (ppm) on 3 study areas in East Feliciana Parish, Louisiana, as found from soil samples collected to a depth of 15 cm.

\begin{tabular}{|c|c|c|c|c|c|c|}
\hline & \multicolumn{2}{|c|}{$\begin{array}{c}\text { Avondale } \\
(\mathrm{N}=12)\end{array}$} & \multicolumn{2}{|c|}{$\begin{array}{l}\text { Shades } \\
(N=14)\end{array}$} & \multicolumn{2}{|c|}{$\begin{array}{c}\text { Blairstown } \\
(\mathrm{N}=16)\end{array}$} \\
\hline & $\bar{x}$ & SE & $\bar{x}$ & SE & $\bar{x}$ & SE \\
\hline P (ppm) & 24.1 & 3.7 & 35.8 & 7.6 & 17.3 & 1.1 \\
\hline $\mathrm{Na}$ (ppm) & 18.2 & 2.1 & 21.5 & 2.0 & 29.5 & 4.6 \\
\hline $\mathbf{K}(\mathrm{ppm})$ & 57.0 & 5.4 & 74.7 & 7.9 & 37.3 & 4.7 \\
\hline $\mathrm{Ca}$ (ppm) & 262.1 & 32.7 & 511.6 & 72.8 & 415.9 & 50.6 \\
\hline $\mathrm{Mg}(\mathrm{ppm})$ & 94.0 & 12.2 & 174.5 & 22.7 & 102.1 & 13.8 \\
\hline pH & 4.9 & 0.1 & 5.2 & 0.1 & 5.1 & 0.1 \\
\hline Cond. ( $\mu$ MHOS) & 53.4 & 5.3 & 69.5 & 6.8 & 61.8 & 5.8 \\
\hline Salts (ppm) & 97.8 & 8.8 & 124.1 & 11.2 & 111.5 & 9.5 \\
\hline
\end{tabular}

describe associations among variables. General linear model procedures (Ray 1982) were used to derive regression coefficients.

\section{Results and Discussion}

Tracks of deer and wild turkey (Meleagris gallopavo) were found proximate to licks during the study. Turkey tracks were noted only once and appeared to be incidental. We are confident that the vast majority of mineral consumption was from deer.

Concern was expressed during review of this manuscript that precipitation could have accounted for a significant proportion of mineral disappearance (as opposed to consumption by deer). Loss of mineral due to runoff was minimized through attention to topography and drainage during selection of lick sites. Some licks were not used during each month of the study and 2 or 3 licks on each property received little use over the entire study period. Although the reason for minimal use of some licks was not known, these licks would have provided an indication of significant loss of mineral other than from consumption had such loss occurred. If mineral loss other than from consumption had been significant we would not have recorded any licks not showing some sign of mineral loss, particularly over extended periods. We believe that mineral loss other than from consumption was minimal.

The estimated number of deer on Avondale, Shades, and Blairstown ranged from $56-79,58-119$, and 130-163, respectively, over the study period. These estimates reflected annual recruitments and mortalities as well as a general trend toward higher deer densities over the study period. Monthly mineral consumption averaged $538.0 \mathrm{~g} /$ deer $(\mathrm{SE}=70.8)$ and varied among study areas $(P<0.001)$ and months $(P=0.007)$.

Monthly mineral consumption from individual licks averaged $3.5 \mathrm{~kg}(\mathrm{SE}=0.2, \mathrm{n}=793)$ and ranged from $0-44.6 \mathrm{~kg}$ on Avondale $(\bar{x}$ $=3.5 \mathrm{~kg}, \mathrm{SE}=0.4), 0-59.5 \mathrm{~kg}$ on Shades $(\bar{x}=5.4 \mathrm{~kg}, \mathrm{SE}=0.4)$, and $0-22.3 \mathrm{~kg}$ on Blairstown $(\bar{x}=1.8 \mathrm{~kg}, \mathrm{SE}=0.2)$. Monthly mineral consumption was similar $(P=0.21)$ on Shades $(\bar{x}=824.6 \mathrm{~g} / \mathrm{deer}, \mathrm{SE}$ $=124.3)$ and Avondale $(\bar{x}=637.9 \mathrm{~g} / \mathrm{deer}, \mathrm{SE}=145.3)$, but lower on Blairstown $(\bar{x}=202.6 \mathrm{~g} /$ deer, $\mathrm{SE}=36.3)$ than on Shades $(P<0.001)$ or Avondale $(P=0.002)$. Salt is provided during winter as part of a cow-calf operation on Blairstown. Deer use of salt intended for cattle may have influenced lick use on that property.

Mineral consumption peaked during April and remained relatively high through October (Fig. 1). Monthly mineral consumption ( $\mathrm{g} /$ deer) was similar $(P \geq 0.11)$ during spring March-May; $\bar{x}=$ 798.2, $\mathrm{SE}=236.6$ ), summer (June-August; $\bar{x}=723.6,135.7$ ) and fall (September-November; $\bar{x}=520.2, \mathrm{SE}=103.8$ ), but was lower $(P \leq 0.02)$ during winter (December-February; $\bar{x}=186.0, \mathrm{SE}=90.9$ ) than during any other season. This differs from reports by others (Dasmann 1971, Weeks and Kirkpatrick 1976, Weeks 1978, Jones and Hanson 1985) that mineral consumption was higher in spring
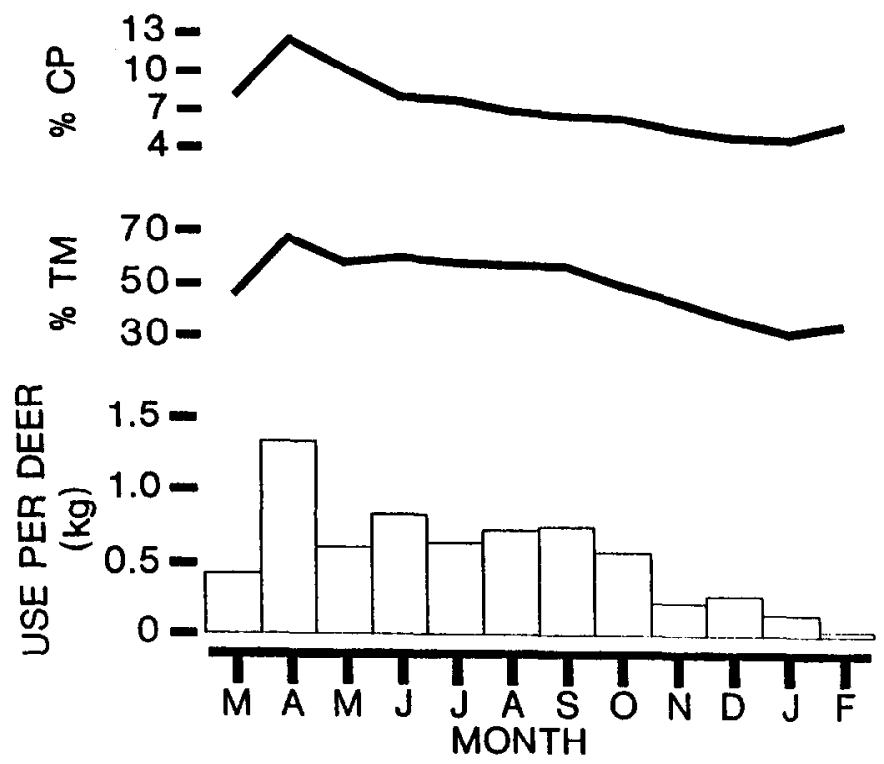

Fig. 1. Average monthly mineral consumption per deer (kg) on 3 properties in East Feliciana Parish, Louisiana, and total moisture (TM) and crude protein (CP) of native plants on forest range in central Louisiana (Campell et al. 1954).

than during any other season, and may be related to the extended growing season in Louisiana compared to more northern latitudes in North America. Lick use was associated with total moisture ( $r=$ $0.926, P<0.001)$ and crude protein $(r=0.809, P=0.001)$ of native plants on forest range in central Louisiana (Campbell et al. 1954) (Fig. 1).

The period of greatest lick use coincided with the fawning and lactational period of does on these areas and the peak antler growth period of bucks. Robbins (1983) described an increased $\mathrm{Na}$ appetite in free-ranging animals associated with gestation and lactation, and mineral requirements for antler development would potentially be greatest during peak growth. However, we believe that lick use was primarily influenced by dietary characteristics rather than the reproductive status of does or the antler development stage of bucks because of the high associations reported above.

There was no association between mineral consumption from individual licks and soil pH $(r=0.110, P=0.505)$ or soil concentrations of $\mathrm{Na}(r=0.103, P=0.5341), \mathrm{Ca}(r=0.098, P=0.554)$, or $\mathrm{Mg}(r$ $=0.146, P=0.377)$. Mineral consumption from licks was positively associated with soil $\mathbf{P}(r=0.657, P<0.001)$ and $\mathrm{K}(r=0.512$, $P<0.001)$ concentrations. The association between lick use and soil $\mathrm{K}$ was not significant $(r=0.265, P=0.245)$ when only licks in forested areas were included, indicating that the association probably resulted from higher use of licks in previously fertilized pasture areas as opposed to a response to soil $\mathbf{K}$ concentration.

Mineral consumption from licks in forested areas was positively associated with soil $\mathrm{P}$ concentration $(r=0.666, P=0.001)$. Soil $\mathrm{P}$ was not associated with lick use on Blairstown $(r=-0.150, P=$ $0.594)$, but was associated with use on Avondale $(r=0.638, P=$ $0.026)$ and Shales $(r=0.608, P=0.036)$. Lower use of licks on Blairstown may have affected associations on that area. The model of monthly mineral consumption from individual licks $(\mathrm{kg})$ based on soil P concentration (ppm) on Avondale and Shades was:

$$
\text { Consumption }=202.67\left(\text { Soil P) }-1.06\left(\text { Soil } \mathrm{P}^{2}\right)\right.
$$

Increased lick use on soils with higher $P$ concentration could not be explained by stating that deer were trying to compensate for low dietary $\mathbf{P}$ through ingestion of higher $\mathbf{P}$ soils along with minerals 
from licks. The most tenable explanation is that deer spent more time feeding in areas with higher soil $P$ because these areas contained vegetation with higher $P$ content; therefore, lick use was greater in those areas. Deer on range deficient in $\mathbf{P}$, as has been suggested for upland pine-hardwood habitats in the southeastern United States (Lay 1957, Short et al. 1969, Blair et al. 1977, Jones and Hanson 1985), would tend to select food plants with higher $P$ content (Verme and Ullrey 1984).

\section{Implications}

The practice of supplying mineral mixtures to free-ranging deer to supplement nutrition on native range is a practice of unproved efficacy. Mineral consumption may vary among locations and in relation to annual cycles. However, individuals supplying mineral mixtures can realistically expect utilization of the products because of the attractiveness of salt to deer.

Response of free-ranging deer to practices designed to supplement nutrition will inherently vary among regions, areas within regions, and over time due to differences in native dietary composition and quality. Effects from such practices would be expected to vary as well. This study did not attempt to describe response of free-ranging deer to mineral supplementation in the broad sense, but rather to describe one piece of the puzzle. Studies in additional regions and under different conditions will be required for this topic to be addressed in a broader sense.

\section{Literature Cited}

Blair, R.M., H.L. Short, and E.A. Epps, Jr. 1977. Seasonal nutrient yield and digestibility of deer forage from a young pine plantation. J. Wildl. Manage. 41:667-676.

Campbell, R.S., E.A. Epps, Jr., C.C. Moreland, J.L. Farr, and F. Bonner. 1954. Nutritive values of native plants on forest range in central Louisiana. La. Agr. Exp. Sta. Bull. 448.
Chapman, H.D. 1984. Louisiana beef cattle production. La. Coop. Ext. Serv. Pub. 2239.

Chapman, H.o. 1985. Minerals for beef cattle. La. Coop. Ext. Serv. Pub. 2227.

Dasmann, W. 1971. If deer are to survive. Stackpole Books, Harrisburg, $\mathrm{Pa}$.

Hayne, D.W. 1949. An examination of the strip census method for estimating animal populations. J. Wildl. Manage. 13:145-157.

Jones, K.L., and H.C. Hanson. 1985. Mineral licks, geophagy, and biochemistry of North American ungulates. Iowa State Univ. Press, Ames.

Lay, D.W. 1957. Browse quality and the effects of prescribed burning in southern pine forests. J. Forest. 55:342-347.

Ray, A.A., ed. 1982. SAS user's guide: statistics. SAS Institute, Cary, N.C. Robbins, C.T. 1983. Wildlife feeding and nutrition. Academic Press, N.Y. Schultz, S.R. 1990. Effects of artificial mineral licks on white-tailed deer. Ph.D. Diss., Louisiana State Univ., Baton Rouge.

Short, H.L., J.D. Newsom, G.L. McCoy, and J.F. Fowler. 1969. Effects of nutrition and climate on southern deer. Trans. North Amer. Wildl. and Natur. Resour. Conf. 34:137-146.

Steel, R.G.D., and J.H. Torrie. 1980. Principles and practices of statistics. McGraw-Hill Book Co., N.Y.

Stockstad, D.S., M.S. Morris, and E.C. Lory. 1952. Chemical characteristics of natural licks used by big game animals in western Montana. North Amer. Wildl. Conf. 18:247-258.

U.S. Soil Conserv. Serv. 1968. General soil map-East Feliciana Parish, Louisiana. USDA and Louisiana Agr. Exp. Sta.

Verme, L.J., and D.E. Ullrey. 1984. Physiology and nutrition. p. 91-118. In: L.K. Halls (ed.) White-tailed deer, ecology and management. Stackpole Books, Harrisburg, $\mathrm{Pa}$.

Weeks, H.P., Jr. 1978. Characteristics of mineral licks and behavior of visiting white-tailed deer in southern Indiana. Amer. Midland Natur. 100:384-395.

Weeks, H.P., Jr., and C.M. Kirkpatrick. 1976. Adaptations of white-tailed deer to naturally occurring sodium deficiencies. J. Wildl. Manage. 40:610-625. 